\title{
TINDAK TUTUR IMPERATIF BAHASA MELAYU DIALEK SELIMBAUKABUPATEN KAPUAS HULU (KAJIAN PRAGMATIK)
}

\author{
Muhammad Thamimi' ${ }^{1}$, Wiendi Wiranty ${ }^{2}$ \\ ${ }^{1}$ IKIP PGRI Pontianak \\ ${ }^{2}$ IKIP PGRI Pontianak \\ thamibenzema09@gmail.com
}

\begin{abstract}
Abstrak
Tujuan umum dalam penelitian ini adalah untuk "Mendeskripsikan Tindak Tutur Imperatif Bahasa Melayu dialek Selimbau Kabupaten Kapuas Hulu". Jenis penelitian kualitatif.Teknik pengumpulan data yang digunakan dalam penelitian ini adalah teknik observasi, simak libat cakap, wawancara, dan teknik catat. Alat pengumpul data yang digunakan adalah peneliti sendiri sebagai instrument utama yang di bantu alat-alat berupa alat rekam, catatan lapangan, pedoman wawancara. Teknik pemeriksaan keabsahan data dalam penelitian ini menggunakan ketekunan atau keajegan pengamatan, trianggulasi sumber dan teori. Teknik analisis data dalam penelitian ini menggunakan model analisis interaktif Miles dan Huberman. Hasil penelitian ini menyatakan bahwa terdapat Tindak Tutur Imperatif pada bahasa Melayu dialek Selimbau Kabupaten Kapuas Hulu.
\end{abstract}

Kata Kunci: bahasa melayu dialek selimbau, tindak tutur, imperatif

\begin{abstract}
Abstrack
The general objective of this research is to "Describe the Imperative Actions of Malay Language in the dialect of Selimbau Kapuas Hulu Regency". This research is included in the type of qualitative research. Data collection techniques used in this study are observation techniques, see skillful involvement, interviews, and note-taking techniques. The data collection tool used is the researchers themselves as the main instruments that are assisted by tools such as recording tools, field notes, interview guidelines, and cameras. The technique of checking the validity of the data in this study used persistence or regularity of observation, source triangulation and theory. Data analysis techniques in this study used the interactive analysis model of Miles and Huberman.
\end{abstract}

Keywords: dialect malay language selimbau, tindak tutur, imperative

\section{PENDAHULUAN}

Bahasa adalah salah satu alat komunikasi, melalui bahasa, manusia dapat saling berhubungan (berkomunikasi), saling berbagai pengalaman, saling belajar dari yang lain, dan meningkatkan kemampuan intelektual. Di dalam komunikasi, dapat diasumsikan bahwa seorang penutur mengartikulasi tuturan dengan maksud untuk 
menginformasikan sesuatu kepada mitra tuturannya, dan mengharap mitra tuturnya (pendengar) dapat memahami apa yang hendak dikomunikasi. Untuk itu, penutur harus selalu berusaha agar tuturannya mematuhi prinsip kerja sama, kesantunan, etika, maupun estetika.

Tindak tutur merupakan gejala individual, bersifat psikologis yang merupakan sepenggal tutur yang dihasilkan dari interaksi sosial yang melibatkan penutur dan memiliki kemampuan bahasa serta melibatkan hal yang dibicarakan. Maka, dalam setiap proses komunikasi terjadilah tindak tutur. Searle (Rohmadi, 2010: 32) mengatakan bahwa "Dalam semua komunikasi linguistik terdapat tindak tutur. Ia berpendapat bahwa komunikasi bukan sekedar lambang, kata atau kalimat, tetapi akan lebih tepat apabila disebut produk atau hasil dari lambang, kata atau kalimat yang berwujud perilaku tindak tutur (the performance of speech acts)". Lebih tegasnya bahwa tindak tutur adalah produk atau hasil dari suatu kalimat dalam kondisi tertentu dan merupakan kesatuan terkecil dari komunikasi linguistik yang dapat berwujud pernyataan perintah, himbauan, dan larangan atau yang lainnya.Senada dengan pendapat, Cummings (2007: 362) mengatakan bahwa "Tindak tutur merupakan fenomena pragmatik penyelidikan linguistik klinis yang sangat menonjol".

Setiap komunikasi antar individu pasti saling menyampaikan informasi yang berupa pikiran, gagasan, maksud, perasaan maupun emosi secara langsung. Saat berkomunikasi sangat penting untuk dipahami oleh penutur setiap kalimat yang diucapkannya. Penggunaan kalimat perintah (imperatif) yang tepat pada saat berkomunikasi sangat menentukan keberhasilan dalam menyampaikan maksud dan tujuan yang ingin dicapai oleh penutur. Rahardi (2005: 79) mengemukakan bahwa "Kalimat imperatif mengandung maksud memerintah atau meminta agar mitra tutur melakukan suatu sebagaimana diinginkan penutur".

Bahasa Melayu dialek Selimbau yang selanjutnya disingkat BMDS merupakan bahasa daerah (vernacular language) yang dipakai oleh masyarakat di kecamatan Selimbau sebagai alat komunikasi. BMDS seperti bahasa-bahasa lain juga tidak luput 
dari pengaruh bahasa asing. Hal ini disebabkan karena bahasa sebagai alat komunikasi, alat untuk berpikir, alat untuk menunjukkan hasil karya dan alat untuk menunjukkan identitas, maka bahasa beserta unsur-unsurnya dapat dievaluasi, diubah, diperbaiki, diganti dan disesuaikan dengan perkembangan zaman, dan untuk keperluan pemakainya, maka sah saja untuk memasukkan unsur bahasa asing.Satu diantara alasan peneliti memilih bahasa Melayu dialek Selimbau adalah untuk mendokumentasikan bahasa Melayu dialek Selimbau.

Alasan peneliti memilih BMDS sebagai objek penelitian. Karena masyarakat masyarakat Selimbau sebagai penutur asli bahasa Melayu dialek Selimbau. BMDS sebagai bahasa daerah yang masih dipakai sebagai alat komunikasi yang hidup dan dibina oleh masyarakat pemakainya, dihargai dan dipelihara oleh masyarakat. karena bahasa-bahasa itu adalah bagian dari kebudayaan. Bahasa daerah harus tetap dipelihara karena merupakan bagian dari kebudayaan nasional yang hendak dipersatukan.

Pragmatik pada hakikatnya mengarah kepada perwujudan kemampuan pemakai bahasa untuk menggunakan bahasanya sesuai dengan faktor-faktor penentu tindak komunikatif, dengan memperhatikan prinsip-prinsip penggunaan bahasa secara tepat. Sudah jelas bahwa ilmu pragmatik sangat berkaitan dengan bahasa yang digunakan untuk berkomunikasi. Di dalam ilmu pragmatik ada beberapa kajian yang dibahas diantarnya referensi, inferensi, praanggapan, implikatur, deiksis, tindak tutur, prinsip kesopanan, dan aspek-aspek struktur wacana. Dari kajian yang ditawarkan oleh pragmatik peneliti tertarik untuk meneliti tindak tutur imperatif yang terdapat di dalam BMDS.

Pragmatik adalah studi kebahasaan yang terikat konteks. Konteks memiliki peranan kuat dalam menentukan maksud penutur dalam berinteraksi dengan lawan tutur. Cruse (Louise, 2007:2) mengatakan bahwa pragmatik dapat dianggap berurusan dengan aspek-aspek informasi yang disampaikan melalui bahasa yang (a) tidak dikodekan oleh kovensi yang diterima secara umum dalam bentuk-bentuk linguistik yang digunakan, namun, yang (b) juga muncul secara alamiah dari dan bergantung 
pada makna-makna yang dikodekan secara kovensional dengan konteks tempat penggunaan bentuk-bentuk tersebut. Oleh karena itu, informasi yang kita dapatkan dapat diperjelas dengan cara melibatkan sejumlah proses yang saling berhubungan, apa yang disampaikan dapat dipahami dan dimengerti oleh orang lain.Yacob (Subroto, 2011: 9) mengatakan bahwa pragmatik adalah kajian kondisi-kondisi penggunaan bahasa manusia yang ditentukan oleh konteks kemasyarakatan. Yang terpenting dalam hal ini adalah penggunaan bahasa yang melbatkan penutur dan mitra tutur.

Ada beberapa alasan yang mendasari peneliti untuk melakukan penelitian ini yaitu, pertama karena peneliti ingin memperkenalkan BMDS kepada masyarakat luas, kedua BMDS mulai mengalami perubahan, khususnya dalam kalangan remaja, hal ini disebabkan masuknya pengaruh bahasa-bahasa lain ke dalam BMDS, ketiga peneliti ingin menyajikan atau mengenalkan bentuktindak tutur imperatifdalam BMDS. Melalui penelitian ini, diharapkan masyarakat Selimbau lebih menghargai dan mencintai bahasa daerah yang digunakan untuk berkomunikasi, para remaja pun ikut berpartisipasi melestarikan bahasa daerah yakni warisan yang harus selalu dijaga supaya tidak punah, sehingga bahasa asing yang muncul hanya sebagai variasi bahasa dalam berkomunikasi.

Bahasa Melayu Dialek Selimbau yang disingkat BMDS merupakan bahasa yang mayoritas digunakan oleh masayarakat yang berada di kecamatan Selimbau. Penggunaan BMDS dituturkan dalam situasi resmi maupun tidak resmi. Penggunaan BMDS dalam situasi resmi seperti dalam upacara adat, sedangkan dalam situasi tidak resmi BMDS digunakan dalam lingkungan keluarga dan pada saat berkomunikasi antara penutur bahasa tersebut baik di toko maupun di rumah.

BMDS dipakai dan ditutur oleh penduduk suku melayu yang terdapat dikecamatan Selimbau terdiri dari empat belas desa di antaranya beberapa desa Gudang Hilir, desa Gudang Hulu, desa Dalam, desa Nibung, desa Piasak, desa Leboyan, desa Engkerengas, desa Tempurau, benuis Gerayau, desa Sekulat, desa Mawan, desa Vega, desa Semalah, dan desa Jongkong Hulu. Seiring perkembangan 
zaman bahasa melayu Dialek Kapuas Hulu (BMDS) yang digunakan oleh penutur pada desa Nibung, Engkerengas, Tempurau, Sekulat, dan Pega sudah mulai tercemar oleh pengaruh dialek luar sehingga peniliti semakin memantapkan diri untuk meneliti Relasi Semantik Verba Berjalan Dialek Selimbau.

BMDS sebagai bahasa daerah memiliki penutur 14.382 jiwa terdiri dari 7.254 jiwa laki-laki dan 7.128 jiwa perempuan yang tergabung dalam 3.897 kepala keluarga. Sebagian besar penduduk di kecamatan selimbau ini memeluk islam dengan jumlah 13.528 jiwa (sumber data kecamatan Selimbau). Secara geografis batas Kecamatan Selimbau sebagai berikut; 1) Sebelah Utara berbatasan dengan Kecamatan Batang Lupar yang sebagian besar masyarakatnya pemakai bahasa Dayak Iban. 2) Sebelah Selatan berbatasan dengan Kecamatan Hulu Gurung yang sebagian besar masyarakatnya pemakai bahasa Melayu.3) Sebelah Barat berbatasan dengan Kecamatan Suhaid yang sebagian besar yang masyarakatnya pemakai bahasa Melayu. 4) Sebelah Timur berbatasan dengan Kecamatan Jongkong yang sebagian besar masyarakatnya pemakai bahasa Melayu.

Alasan peneliti memilih tindak tutur imperatif sebagai objek penelitian karena didasarkan beberapa hal. Pertama, karena tindak tutur imperatif imperatif sering digunakan masyarakat untuk berkomunikasi. Kedua, tindak tutur imperatif belum pernah diteliti sebelumnya.Ketiga, untuk mengetahui bentuk tindak tutur imperatif dalam BMDS.

Istilah imperatif lazim digunakan untuk menunjukkan satu diantara tipe kalimat bahasa Indonesia, yakni kalimat imperatif atau perintah. Keraf (Rahardi, 2005:2) mendifinisikan bahwa kalimat perintah sebagai kalimat yang digunakan untuk menyuruh orang lain melakukan sesuatu. Kalimat imperatif secara fungsional tidak hanya memiliki makna pragmatik memerintah saja melainkan dapat memiliki maknamakna pragmatik lainnya.Berdasarkan fenomena yang telah peneliti paparkan, peneliti beranggapan bahwa penelitian mengenai wujud pragmatik imperatif perintah, himbauan, larangan, dan ajakan sangat menarik dan perlu untuk dipahami. 
Imperatif adalah kalimat yang berisi perintah kepada orang lain untuk melakukan sesuatu atau kalimat yang dipakai untuk mendapatkan tanggapan sesuai dengan kehendak penuturnya. Fungsi kalimat imperatif adalah meminta atau melarang seseorang untuk melakukan sesuatu. Kridalaksana (Putrayasa, 2009: 31) "menyebut kalimat perintah dengan istilah imperatif, yakni kalimat yang mengandung intonasi imperatif". Rahardi (2005: 79) mendefinisikan bahwa "Imperatif adalah kalimat yang mengandung maksud memerintah atau meminta agar mitra tutur melakukan suatu sebagaimana diinginkan penutur”. Kalimat impertif dalam bahasa Indonesia dapat berkisar antara suruhan yang sangat keras atau kasar sampai dengan permohonan yang sangat halus dan santun.

Rahardi (2010: 95) "Kalimat perintah adalah kalimat yang berfungsi untuk memerintah lawan bicara tentang sesuatu seperti yang terkandung dalam kalimat tersebut". Cook (Putrayasa, 2009: 31) mendefinisikan bahwa "Kalimat perintah adalah kalimat yang dibentuk untuk memancing responsi yang berupa tindakan atau perbuatan".Kalimat perintah merupakan kalimat yang menyuruh seseorang untuk melakukan perbuatan misalnya, menyuruh, melarang, dan memerintah sesuai dengan kenginan penuturnya.

Kalimat larangan termasuk perintah, yaitu perintah atau tindakan yang melarang suatu perbuatan, memerintahkan supaya tidak melakukan. Menurut sifatnya dapat dibedakan adanya kalimat larangan yang tegas, yang biasa, dan yang halus. Menurut Chaer (2009: 198) menyatakan bahwa "Kalimat larangan adalah mengharapkan jawaban berupa tidak melakukan sesuatu yang disebutkan dalam kalimat itu". Oleh karena itu, dalam kalimat larangan ini digunakan kata-kata pencegahan, seperti kata jangan, dilarang, tidak boleh, dan gabungan kata sebaiknya. Sama halnya dengan kalimat perintah, kalimat larangan ada yang tegas, yang biasa, dan yang halus atau sopan.

Kajian pustaka yang relevan juga dibutuhkan sebagai acuan untuk penelitianpenelitian yang terlebih dahulu melakukan penelitian tentang kesantunan tindak tutur imperatif Lusiana dan Nidya (2016) dala jurnalnya yang berjudul "Kesantunan 
Tindak Tutur Imperatif Dalam Pengajaran Bahasa Inggris Pada Mahasiswa Di Kabupaten Dharmasraya". Dalam hasil penelitiannya terdapat strategi kesantunan diterapkan dalam pengajaran bahasa Inggris, khususnya pada mahasiswa FKIP Jurusan PGSD semester 2 Mata Kuliah "Bahasa Inggris di SD" di Universitas Dharmas Indonesia Kabupaten Dharmasraya menjadi strategi kesantunan konteks ketika ditemukan kesantunan tindak tutur imperatif dalam bentuk memaksa, mengajak, menyuruh, mendesak, memohon, menyarankan, dan memerintah dengan ditemukannya tiga dari empat fungsi bahasa.

Berdasarkan latar belakang di atas, peneliti ingin mengetahui lebih dalam mengenai "Tindak Tutur Imperatif Bahasa Melayu Dialek Selimbau". Untuk mengetahui seberapa banyak kalimat perintah, himbauan, dan larangan yang ada dalam BMDS.

\section{METODE}

Penelitian ini termasuk ke dalam jenis penelitian kualitatif yang bersifat deskriptif.Penelitian ini mencatat secara teliti semua fenomena kebahasaan yang senyatanya ada, meneliti, dan memeriksa sistem bahasa berdasarkan data yang sebenarnya (Subroto, 2007:8). Metode yang digunakan untuk memberikan gambaran mengenai hasil analisis Tindak tutur imperatif dalam Bahasa Melayu Dialek Selimbau. Menurut Moleong (1991:16) di dalam metode deskriptif data yang dikumpulkan dapat berasal dari catatan-catatan, naskah wawancara, photo, video, tape, dokumen pribadi, memo, atau catatan, dan doumen resmi lainnya. Data dalam penelitian ini berupa kata yang mengandung Tindak Tutur Imperatif yang digunakan oleh masyarakat Melayu Kecamatan Selimbau. Teknik pengumpalan data yang digunakan dalam peneltian ini adalah teknik observasi, simak libat cakap, wawancara, dan teknik catat.alat pengumpul data yang digunakan adalah peneliti sendiri sebagai instrumen kunci dalam pengumpulan data. Dalam hal ini, peneliti dibantu oleh alatalat pengumpul data berupa alat rekam, catatan lapangan, pedoman wawancara. Teknik pemeriksaan keabsahan data dalam penelitian ini adalah trianggulasi sumber 
dan teori. Teknik analisis data dalam penelitian ini menggunakan model analisis interaktif Miles dan Huberman.

\section{HASIL DAN PEMBAHASAN}

Kalimat perintah bahasa Melayu dialek Selimbau pada masyarakat Kecamatan Selimbau, sering digunakan masyarakat dalam berkomunikasi sehari-hari. Berpijak pada rumusan masalah dan deskripsi data di atas, maka pada bagian ini akan dideskripsikan penganalisisan tehadap hasil data yang telah diperoleh selama penelitian dilakukan. Berikut analisis dan hasil penelitian kalimat perintah, kalimat himbauan, kalimat larangan, dan kalimat ajakan dalam bahasa Melayu dialek Selimbau pada masyarakat Kecamatan Selimbau Kabupaten Kapuas Hulu .

\section{Kalimat perintah bahasa Melayu dialek Selimbau Kabupaten Kapuas}

\section{Hulu}

Kalimat perintah bahasa Melayu dialek Selimbau pada masyarakat Kecamatan Selimbau yang dimaksud di sini adalah kalimat perintah yang disesuaikan dengan konteks situasi yang terjadi pada masyarakat Kecamatan Selimbau Kabupaten Kapuas Hulu serta terdapat kalimat perintah yang halus, permohonan, ajakan, permintaan, harapan, anjuran, pemberian ucapan selamat, mengizinkan, bujukan, pemberian izin, dan kalimat perintah kasar. Rahardi (2010: 95) "Kalimat perintah adalah kalimat yang berfungsi untuk memerintah lawan bicara tentang sesuatu seperti yang terkandung dalam kalimat tersebut". Berikut ini adalah analisis data dan hasil penelitian yang kerap terjadi di masyarakat Kecamatan Selimbau Kabupaten Kapuas Hulu .

\section{a. Kalimat Perintah Halus}

Kalimat perintah halus adalah kalimat perintah dengan kadar sangat halus yang dituturkan oleh masyarakat Kecamatan Selimbau. kalimat perintah halus disertai dengan sikap penutur yang lebih merendah dibandingkan dengan sikap penutur pada waktu menuturkan kalimat perintah larangan. Kalimat perintah halus ditandai dengan pemakaian penanda perintahsilahkan, tolong, harap, dan diminta dengan hormat. Berikut ini adalah tindak tutur 
kalimat perintah halus yang dituturkan oleh masyarakat Kecamatan Selimbau(penutur) kepada mitra tutur.

(1) "Sila makan bah kian semua!".

Artinya:

(“Silahkan makan semuanya!”.)

Situasi Tuturan:

Dituturkan oleh seorang ibu yang mempersilakan teman-teman anaknya untuk makan.

Berdasarkan tindak tutur (1) di atas dapat dibuktikan bahwa tuturantuturan di atas adalah tuturan kalimat perintah halus. Yang terjadi di masyarakat pada acara-acara tertentu. Tindak tutur (1) pada intinya mengandung makna bahwa ada seorang ibu yang memerintahkan kepada teman-teman anaknya untuk makan semua makanan yang sudah disediakannya. Jadi tindak tutur ini termasuk kalimat perintah halus yang terjadi di masyarakat Kecamatan Selimbau.

\section{b. Kalimat perintah permohonan}

Kalimat perintah permohonan adalah kalimat yang isinya memohon kepada mitra tutur agar mau melaksanakan apa yang diperintahkan oleh sang penutur. Kalimat perintah permohonan ini di tandai dengan kata mohon. Berikut ini adalah tindak tutur kalimat perintah permohonan yang dituturkan oleh penutur kepada mitra tutur.

(2) "minta rela doakan kami semua selamat bait datang Pinun".

Artinya:

("mohon doakan kami semua selamat sampai tujuan".)

Situasi Tuturan:

Dituturkan oleh seorang bapak kepada rekan nya dah mohon doa agar selamat sampai tujuan.

Berdasarkan tindak tutur (2) di atas dapat dibuktikan bahwa tuturantuturan ini adalah tuturan kalimat perintah permohonan. Dalam perubahan konstruksi imperatif menjadi kalimat perintah permohonan ternyata tidak 
terdapat perubahan makna. Tindak tutur (2) pada intinya mengandung makna bahwa ada seorang bapak yang memohon kepada rekannya agar didoakan semoga selamat sampai tujuan selama perjalannya. Tindak tutur ini termasuk jenis tuturan kalimat perintah permohonan, karena penutur memberikan perintah permohonan kepada mitra tutur, seolah-olah harus dilakukan.

\section{c. Kalimat perintah ajakan}

Kalimat perintah ajakan adalah kalimat yang mengandung makna ajakan agar mitra tutur mau mengikuti apa yang dikehendaki oleh sang penutur. Sehingga ada kerja sama yang baik antara penutur dan mitra tutur dengan adanya ajakan tersebut ada hubungan yang sangat erat anatar penutur dan mitra tutur. tuturan ini ditandai dengan adanya kata ajakan, seperti ayo, yok, dan partikel lah. Berikut ini adalah tindak tutur kalimat perintah ajakan yang dituturkan oleh penutur kepada mitra tutur.

(3) "aboh məh bəjalan kita, udah lama? kita nak bejalan". Artinya:

(“ayolah lah kita jalan, sudah lama kita tidak jalan”)

Situasi tuturan:

Dituturkan oleh seorang teman kepada rekannyapada saat mengajak rekan-rekannya untuk jalan.

Berdasarkan tindak tutur (3) diatas dapat dibuktikan bahwa tuturantuturan ini adalah tindak tutur imperatif. Tuturan ini mengandung makna perintah agar mitra tutur mau melaksanakan apa yang di perintahkan oleh penutur. Tindak tutur (3) pada intinya mengandung makna bahwa ada seorang pria mengajak rekan-rekannya jalan karena mereka sudah lama tidak ngumpul dan jalan sama-sama. Tuturan ini mengandung kalimat perintah ajakan kepada teman-temanya untuk ngumpul dan jalan bersama.

\section{d. Kalimat perintah harapan}

Kalimat perintah harapan adalah kalimat yang mengandung makna harapan agar mitra tutur mau menghendaki apa yang diinginkan penutur.Tuturan ini ditandai dengan adanya kata ajakan, seperti semoga, dan 
harap. Berikut ini adalah tindak tutur kalimat perintah harapan yang dituturkan oleh penutur kepada mitra tutur.

(4) "moga nuan jadi anak yang sholeh".

Artinya:

("Semoga kamu jadi anak yang sholeh")

Situasi tuturan:

Dituturkan oleh seorang bapak kepada anak yatim yang berada dirumahnya agar jadi anak yang sholeh.

Berdasarkan tindak tutur (4) di atas dapat dibuktikan bahwa tuturan ini adalah tuturan kalimat perintah harapan. Dalam tuturan bahasa Melayu dialek Selimbau sangat bervariasi ketika masyarakat Kecamatan Selimbaumemerintah harapan. Tindak tutur (4) mengandung makna tentang bahwa ada seorangbapak berharap anak yatim yang berada dirumahnya agar jadi anak yang sholeh . Tuturan ini terjadi pada saat bapak itu memberikan baju kepada anak yatim itu, dan berharap jadi anak yang berguna bagi ibunya. Tuturan ini termasuk kalimat perintah harapan seorang bapak yang berharap anak itu jadi anak yang shaleh.

\section{e. Kalimat perintah anjuran}

Kalimat perintah anjuran adalah kalimat yang isinya menganjurkan kepada mitra tutur agar mau melaksanakan apa yang diperintahkan oleh sang penutur. Kalimat perintah anjuran ditandai dengan pemakaian penanda perintahsepantasnya. Berikut ini adalah tindak tutur kalimat perintah anjuran yang dituturkan oleh penutur kepada mitra tutur.

(5) "Sepantasnya meh duit yak di tabung pakai lebaran".

Artinya:

("Sepantasnya tabung uangnya untuk lebaran")

Situasi tuturan:

Dituturkan oleh seorang bapak kepada anaknya supaya uangnya ditabung untuk lebaran.

Berdasarkan tindak tutur (5) di atas dapat dibuktikan bahwa tuturan ini adalah tuturan kalimat perintah anjuran. Dalam tuturan bahasa Melayu dialek Selimbau sangat bervariasi ketika masyarakat Kecamatan Selimbaumelakukan 
perintah anjuran. Tindak tutur (5) pada intinya mengandung makna tentang seorang bapak menganjurkan kepada anaknya supaya uangnya ditabung untuk lebaran. Tuturan ini terjadi pada saat anaknya membeli main, dan bapaknya menganjurkan kepada anaknya itu agar di tabung saja uangnya dari pada membeli mainan. Tuturan ini termasuk kalimat perintah yang dituturkan oleh penutur kepada mitra tuturnya.

\section{Kalimat himbauan bahasa Melayu dialek Selimbau pada masyarakat} Kecamatan Selimbau Kabupaten Kapuas Hulu ?

Kalimat himbauan bahasa Melayu dialek Selimbau pada masyarakat Kecamatan Selimbau yang dimaksud di sini adalah kalimat himbauan yang disesuaikan dengan konteks situasi yang terjadi pada masyarakat Kecamatan Selimbau Kabupaten Kapuas Hulu. Serta terdapat kalimat himbauan halus, kasar, mengajak, dan tegas. Berikut ini adalah analisis data dan hasil penelitian yang kerap terjadi di masyarakat Kecamatan Selimbau Kabupaten Kapuas Hulu .

\section{a. Kalimat himbauan halus}

Kalimat himbauan halus adalah kalimat himbauan dengan kadar sangat halus yang dituturkan oleh masyarakat Kecamatan Selimbau. Kalimat himbauan halus disertai dengan sikap penutur yang lebih merendah dibandingkan dengan sikap mitra tutur pada waktu menuturkan kalimat himbauan larangan. Kalimat himbauan halus ditandai dengan pemakaian penanda perintahmohon, harap, dan partikel lah. Berikut ini adalah tindak tutur kalimat himbauan halus yang dituturkan oleh penutur kepada mitra tutur.

(6) "Mohon kepada para jamaah yang ada dituk, minta rela hari jumat kita kumpul di surau nurul iman dalam ranka beymusyawarah peringatan maulid nabi saw".

Artinya: 
("Mohon maaf kepada para jamaah yang berada di tempat ini, supaya pada hari jum'at, agar berkumpul di surau nurul iman dalam rangka bermusyawarah peringatan maulid nabi besar Muhammad Saw")

Situasi tuturan:

Dituturkan oleh seorang ustad menghimbau kepada jamaah yang berada di dalam rumahnya, agar hari jum'at berkumpul di surau nurul iman dalam rangka memperingati isra' mi'raj nabi besar Muhammad Saw.

\section{b. Kalimat himbauan kasar}

Kalimat himbauan kasar adalah kalimat himbauan dengan kadar kasar yang dituturkan oleh masyarakat Kecamatan Selimbau. Kalimat himbauan kasar disertai dengan sikap penutur yang lebih tinggi dibandingkan dengan sikap mitra tutur pada waktu menuturkan kalimat himbauan kasar. Kalimat himbauan kasar ditandai dengan pemakaian penanda himbauaningat, dan jangan. Berikut ini adalah tindak tutur kalimat himbauan kasar yang dituturkan oleh penutur kepada mitra tutur.

(7) "Ingat di jaga ana? ya nusah main kabel nanak ke sentrum".

Artinya:

('Ingat' dijaga anaknya takut bermain kabel, takut kena' setrum")

Situasi tuturan:

Dituturkan oleh seorang bapak menghimbau kepada istrinya di dalam rumah, supaya anaknya dijaga takut bermain kabel takut kena setrum.

\section{Bagaimanakah kalimat larangan bahasa Melayu dialek Selimbau pada masyarakat Kecamatan Selimbau Kabupaten Kapuas Hulu ?}

Kalimat larangan bahasa Melayu dialek Selimbau pada masyarakat Kecamatan Selimbau. Menurut Chaer (2009: 198) menyatakan bahwa "Kalimat larangan adalah mengharapkan jawaban berupa tidak melakukan sesuatu yang disebutkan dalam kalimat itu". Yang dimaksud di sini adalah kalimat larangan yang disesuaikan dengan konteks situasi yang terjadi pada 
masyarakat Kecamatan Selimbau Kabupaten Kapuas Hulu. Serta terdapat kalimat larangan halus, kasar dan tegas. Berikut ini adalah analisis data dan hasil penelitian yang kerap terjadi di masyarakat Kecamatan Selimbau Kabupaten Kapuas Hulu .

\section{a. Kalimat larangan halus}

Kalimat larangan halus adalah kalimat yang isinya melarang dengan kata halus kepada mitra tutur agar mau melaksanakan apa yang diperintahkan oleh sang penutur. Kalimat larangan halus ini di tandai dengan kata mohon maaf. Berikut ini adalah tindak tutur kalimat larangan halus yang dituturkan oleh penutur kepada mitra tutur.

(8) "Maaf bagi undangan semua duduk dulu bah sambil kita nunggu pak ustadz datang".

Artinya:

("Mohon maaf kepada para undangan semua agar duduk dulu menunggu Pak Ustadz")

Situasi tuturan:

Dituturkan oleh panitia kepada para undangan yang hadir di dalam masjid, agar duduk dulu menunggu pak ustadz.

\section{b. Kalimat larangan kasar}

Kalimat larangan kasar adalah kalimat yang isinya melarang dengan kata kasar kepada mitra tutur agar mau melaksanakan apa yang diperintahkan oleh sang penutur. Kalimat larangan kasar ini di tandai dengan kata dilarang, dan jangan. Berikut ini adalah tindak tutur kalimat larangan kasar yang dituturkan oleh penutur kepada mitra tutur.

(9) "Dila rang parkir diak".

Artinya:

("Dilarang parkir disitu")

Situasi tuturan: 
Dituturkan oleh seorang panitia isra'mi'raj kepada seorang bapak yang hendak parkir motor di tepi jalan.

Berdasarkan tindak tutur (9) di atas dapat dibuktikan bahwa tuturantuturan ini adalah kalimat larangan kasar yang terjadi di masyarakat Kecamatan Selimbau. Tindak tutur (9) pada intinya mengandung makna tentang seorang panitia isra'mi'raj melarang kepada seorang bapak yang hendak parkir motor di tepi jalan. Tuturan ini terjadi di depan masjid karena di tepi jalan itu sudah penuh, seorang panitia isra' mi'raj melarang agar motornya tidak di parkir di tepi jalan takut menggangu pengendara lain untuk lewat. Tuturan ini termasuk tuturan kalimat larangan kasar karena dituturkan dengan suara yang nyaring dan tegas. Sehingga mitra tutur seolah-olah takut parkir di tepi jalan itu.

\section{SIMPULAN}

Berdasarkan analisis yang telah dilakukan terhadap data, maka dapat disimpulkan sebagai berikut.

1. Kalimat perintah bahasa Melayu dialek Selimbau pada Kecamatan Selimbau, yaitu: (1) kalimat perintah halus, (2) kalimat perintah permohonan, (3) kalimat perintah ajakan, (4) kalimat perintah permintaan, (5) kalimat perintah harapan, (6) kalimat perintah anjuran, (7) kalimat perintah pemberian ucapan selamat, (8) kalimat perintah mengizinkan, (9) kalimat perintah bujukan, (10) kalimat perintah pemberian izin, (11) kalimat perintah kasar.

2. Kalimat himbauan bahasa Melayu dialek Selimbau pada masyarakat Kecamatan Selimbau Kabupaten Kapuas Hulu , antara lain adalah: (1) kalimat himbauan halus, (2) kalimat himbauan kasar (3) kalimat himbauan mengajak (4) kalimat himbauan tegas.

3. Kalimat larangan bahasa Melayu dialek Selimbau pada masyarakat Kecamatan Selimbau, yaitu: (1) kalimat larangan halus, (2) kalimat larangan kasar, (3) kalimat larangan biasa. 


\section{DAFTAR PUSTAKA}

Chaer, A. (2009). Pengantar Semantik Bahasa Indonesia. Jakarta: Rineka Cipta.

Cummings, L. (2007). Pragmatik Klinis: Kajian tentang Penggunaan dan Gangguan Bahasa Secara Klinis. Yogyakarta: PustakaPelajar.

Edi, S, D. (2007). Pengantar Metode Penelitian Linguistik Struktural. Surakarta: Universitas Sebelas Maret Press.

Lusiana. F, N. (2016). Kesantunan Tindak Tutur Imperatif Dalam Pengajaran Bahasa Inggris Pada Mahasiswa Di Kabupaten Dharmasraya. Jurnal Puitika. 12 (2): 146-147.

Moleong, L, J. (1991). Metodologi Penelitian Kualitatif. Bandung: PT.Remaja Rosdakarya.

Nadar, F,X. (2013). Pragmatik dan Penelitian Pragmatik. Yogyakarta: Graha Ilmu.

Putrayasa, I, B. (2009). Jenis Kalimat dalam Bahasa Indonesia. Bandung: Refika Aditama.

Rahardi, K. (2005). Pragmatik: Kesantunan Imperatif Bahasa Imperatif Bahasa Indonesia. Jakarta: Erlangga.

Rohamdi, M. (2010). Pragmatik Teori dan Analisis. Surakarta: Yuma Pustaka.

Subroto, E. (2007). Pengantar Metode Penelitian Linguistik Struktural. Surakarta: UNS Press.

Tarigan, Henry. G. (2009). Pengajaran Pragmatik. Bandung: Angkasa.

Wijana, I, D, P., \& Muhammad, R. (2011). Analisis Wacana Pragmatik; Kajian Teori dan Analisis. Surakarta: Yuma Pustaka.

Yule, G. (2006). Pragmatik. Yogyakarta: PustakaPelajar. 